UDC 621.921.34-419:620.187

\author{
R. J. Liu*, Y. B. Cao, C. L. Yan, C. R. Zhang, \\ P. B. He (Changsha, China) \\ *rongjunliu@nudt.edu.cn
}

\title{
Preparation and characterization of diamond- silicon carbide-silicon composites by gaseous silicon vacuum infiltration process
}

Diamond-SiC-Si composites have been prepared using gaseous silicon vacuum infiltration. The evolution of the phases and microstructures of the composites have been analyzed using X-ray diffraction technique and scanning electron microscopy. It has been found that the diamond-SiC-Si composite is composed of $\beta$-SiC, diamond, and residual Si. The diamond particles were distributed homogeneously in the dense matrix of the composites. Besides, the effects of particle size and content of diamond on the properties of diamond-SiC-Si composites have been analyzed. The thermal conductivity of the composites increases with particle size and content of diamond. When the particle size and content of diamond are $300 \mu \mathrm{m}$ and $80 \mathrm{wt} \%$, respectively, the thermal conductivity of the composites approaches the value of $280 \mathrm{~W} \cdot \mathrm{m}^{-1} \cdot \mathrm{K}^{-1}$.

Keywords: diamond-SiC-Si composites, microstructure, evolution of phases, vacuum infiltration, thermal conductivity, XRD, scanning electron microscopy.

\section{INTRODUCTION}

A diamond/SiC composite possesses many key physical properties such as the high thermal conductivity, exceptional hardness, and excellent wear resistance. The characteristic of high thermal conductivity of the diamond/SiC composite makes it promising for many industrial applications such as heat spreaders and heat transfer rig, as more demanding thermal management issues arise in the microelectronics industry [1-3]. Such diamond/SiC composites are usually prepared by gaseous/liquid silicon vacuum infiltration of diamond compacts, which inevitably results in the residual silicon. Therefore, to be more exact, the produced composite should be denoted as diamond-SiC-Si composite.

The diamond-SiC-Si composites produced by the liquid silicon infiltration typically need high pressure and high temperature (HPHT) [4-8], and is usually done at pressures of 6-10 $\mathrm{GPa}$ and temperatures of $1700-2100 \mathrm{~K}$. SiC matrix phase is formed as a result of the reaction between diamond and silicon. However, there exist several drawbacks in HPHT liquid silicon infiltration method. Firstly, HPHT method can only produce samples with simple shape, besides, it has a high preparation cost. Secondly, liquid silicon infiltration cannot fully penetrate diamond compact $[5,6]$. This restriction is caused by the closure of pores in the diamond compact due to the sealing effect of the initial formation of silicon carbide on the surface of the compact. Moreover, it can be anticipated that this effect becomes increasingly pronounced with decreasing size of diamond particles [7, 8]. Recently there are a few reports on the preparation of diamond-SiC-Si composites by the liquid silicon infiltration under a low pressure condition, where the 
diamond-SiC-Si composites were successfully fabricated under ambient pressure or vacuum condition [9-11]. However, the liquid silicon infiltration not only gives rise to the postprocessing problems, but also increases the tendency of cracks occurrence in the composites. Therefore, a new method of gaseous silicon vacuum infiltration is put forward to solve these problems.

The purpose of the present work is to propose a new method to prepare diamond-SiC-Si composite, i.e., gaseous silicon vacuum infiltration [12-14]. This process does not need high pressure, so it avoids high preparation costs. Furthermore, gaseous silicon infiltration is a gentle reaction, thus it can avoid selfquenching phenomenon occurred in a liquid silicon infiltration by the rapid reaction between liquid $\mathrm{Si}$ and $\mathrm{C}$. In this paper, the evolution of phase and microstructure of the composites were analyzed using X-ray diffraction technique and scanning electron microscopy. Besides, the effects of a particle size and diamond content on properties of diamond-SiC-Si composites were studied.

\section{EXPERIMENTAL}

Diamond preforms were produced using phenolic resins and commercial diamond powders with four different particle sizes, e.g., 37.5, 75, 150, and $300 \mu \mathrm{m}$. The composition of the diamond preforms was modified by changing contents of a diamond powder and phenolic resin, and the weight percent of diamond particles varied in the range of 40 to $80 \mathrm{wt} \%$. The roles of the phenolic resin included two aspects: first of all, it acted as a binder during the hot mould process used for forming a diamond compact; secondly, the phenolic resin provided carbon source for $\mathrm{Si}-\mathrm{C}$ reaction to form $\mathrm{SiC}$ matrix and prevented the diamond from reacting with silicon.

For the preparation of diamond preforms, diamond powder was mixed with phenolic resin solution (anhydrous alcohol was used as the solvent) to form slurry, then the slurry was dried in drying oven to obtain the phenolic resin modified diamond powder. The resulting powder was compacted to shape with dimension of $35 \mathrm{~mm}$ in length, $30 \mathrm{~mm}$ in width and $5 \mathrm{~mm}$ in thickness under pressure of $40 \mathrm{MPa}$ and temperature of $200{ }^{\circ} \mathrm{C}$. The compacts were then pyrolyzed at $1000{ }^{\circ} \mathrm{C}$ for $1 \mathrm{~h}$ in flowing argon to form the preforms for gaseous silicon vacuum infiltration. At last, the obtained diamond preforms (green body) and silicon powders were loaded into a graphite crucible (schematically shown in Fig. 1). The green body was located on the top of silicon powders with a certain distance between silicon powders and green body to avoid liquid silicon infiltration at high temperature. Subsequently, the crucible was placed in a graphite furnace and heated to $1600^{\circ} \mathrm{C}$ $\left(10^{\circ} \mathrm{C} \mathrm{min}^{-1}\right.$ heating rate) in vacuum. Finally, $\mathrm{Si}$ vapor produced by melting $\mathrm{Si}$ penetrated into a perform and reacted with carbon at $1600^{\circ} \mathrm{C}$ for $1 \mathrm{~h}$ in vacuum $(\sim 20 \mathrm{~Pa})$.

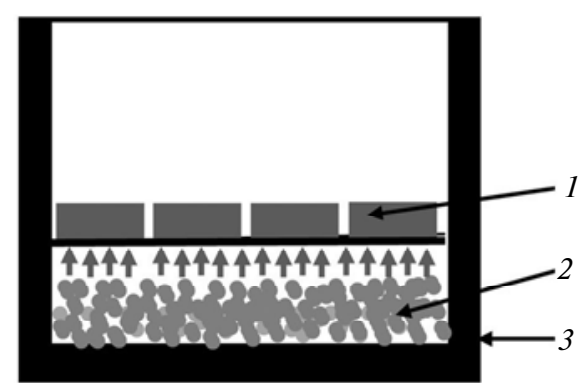

Fig. 1. Set-up for the gaseous silicon infiltration: diamond preform (1), Si powder (2), graphite crucible (3). 
The samples were cut into $3 \times 4 \times 35 \mathrm{~mm}$ specimens and polished for three-point bending test in a WDW-100 (Changchun Research Institute of Testing Machines, Jilin, China) universal testing machine, with a crosshead speed of $0.5 \mathrm{~mm} / \mathrm{min}$ and a span of $30 \mathrm{~mm}$. The phase compositions of the composites were characterized by X-ray diffraction (XRD, D8 Advance, Bruker/Axs Corp., Germany) with $\mathrm{Cu} \mathrm{K} \alpha$ radiation. The thermal conductivity was calculated from the measured thermal diffusivity determined using a NETZSCH LFA 427 flash thermal conductivity meter, the measured density, and an estimated value of the specific heat of the composites. The microstructures of the composites were studied by scanning electron microscopy (SEM, S4800 Hitachi, Japan).

\section{RESULTS AND DISCUSSION}

The XRD patterns of a green diamond compact and diamond-SiC-Si composite are shown in Fig. 2. The diamond compact is composed of diamond particles and pyrolytic carbon derived from phenolic resin. However, only diamond peaks are shown in the XRD patterns for diamond compact, indicating the amorphous state of the pyrolytic carbon. It can be observed from XRD patterns of diamond-SiC-Si composite (see Fig. 2, 2) that the obtained composite consists of diamond, $\beta$-SiC, and $\mathrm{Si}$ after gaseous silicon infiltration. The peaks of Si exist and are strong, indicating that the $\mathrm{Si}$ remains in the composite despite reaction of carbon and $\mathrm{Si}$ leading to formation of $\beta-\mathrm{SiC}$ [15]. As far as the free silicon is concerned, unreacted Si vapour recondenses as liquid on the wall surface of pore channels and fills in the pores of the preform to form a dense composite; as a result, the remnant $\mathrm{Si}$ appears in the final composite. Meanwhile, the diamond phase remains in the composites; however, this can not rule out that a few diamonds reacted with $\mathrm{Si}$.

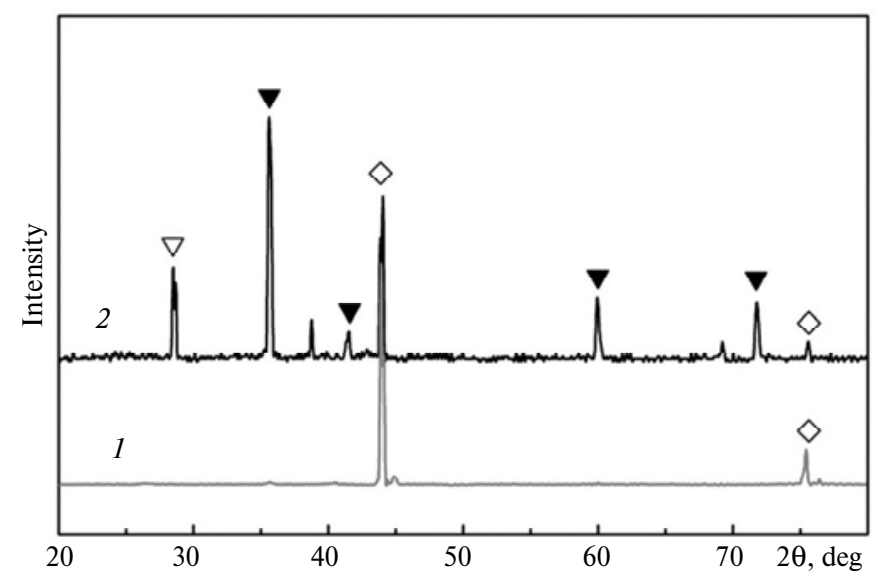

Fig. 2. XRD patterns of (1) diamond compact and (2) diamond-SiC-Si composite: diamond $(\diamond)$, $\operatorname{SiC}(\boldsymbol{\nabla}), \operatorname{Si}(\nabla)$.

Figure 3 shows the effects of the mean particle size of diamond on the bending strength and thermal conductivity of diamond-SiC-Si composites. All the samples have the same diamond content of $40 \mathrm{wt} \%$, and the particle size of diamond ranges from 37.5 to $300 \mu \mathrm{m}$. The thermal conductivity of the composites increases with diamond particle size, and approaches a maximum value of $138.1 \mathrm{~W} \cdot \mathrm{m}^{-1} \cdot \mathrm{K}^{-1}$ at the diamond particle size of $300 \mu \mathrm{m}$. The increase of the thermal conductivity with diamond grain size increasing from 37.5 to $300 \mu \mathrm{m}$ can be explained based on a "two-zone" microstructure model [1] of diamond grain (schematically shown in 
Fig. 4). According to this model, the diamond particles in the composites are comprised of two zones: an eroded surface layer of a certain thickness with a moderate thermal conductivity and a core of pristine diamond with undisturbed high thermal conductivity. The grain size of diamond particles will become smaller for surface $\mathrm{SiC}$ layer induced by the $\mathrm{Si}-\mathrm{C}$ reaction after silicon infiltration. Because the surface $\mathrm{SiC}$ layer thickness is considered to be dependent on diamond grain sizes, thus the diamond particles with smaller size have a thicker eroded $\mathrm{SiC}$ layer. Therefore, the composites with a larger size of diamond particles maintain more volume percent of pristine diamond and show high thermal conductivity.

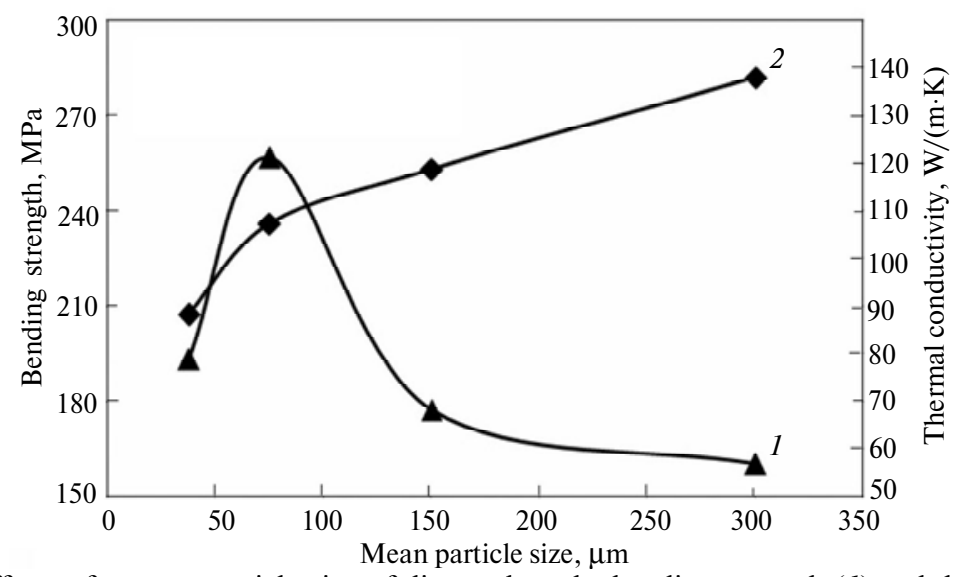

Fig. 3. Effects of a mean particle size of diamond on the bending strength (1) and thermal conductivity (2) of diamond-SiC-Si composites.

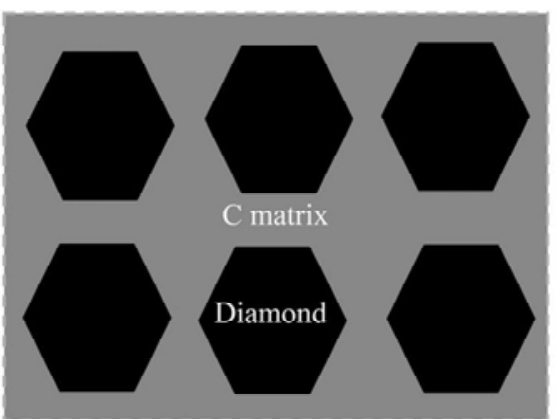

$a$

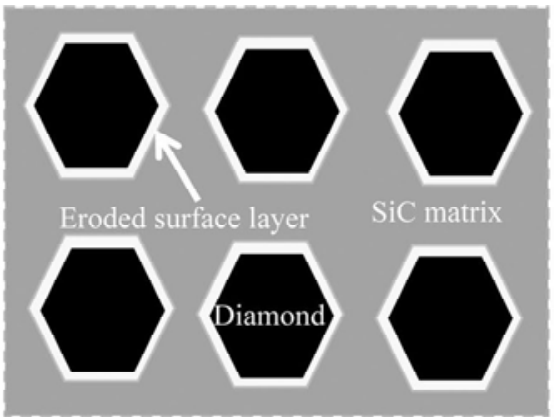

Fig. 4. Diagram of (a) green body before Si infiltration and $(b)$ composite after Si infiltration (diamond/SiC composite).

The bending strength of the composites increases when the particle size of diamond increases from 37.5 to $75 \mu \mathrm{m}$, and then decreases with the further increase of diamond particle size. The diamond-SiC-Si composite reaches the maximum value of $256.8 \mathrm{MPa}$ at the diamond particle size of $75 \mu \mathrm{m}$. As far as particles of reinforced ceramic matrix composite are concerned, the reinforced particles with too large size are likely to break, which will lead the prepared composites to possess low bending strength. Meanwhile, the reinforced particle with too small size is easy to be eroded in the silicon infiltration, thus the strengthening effect of the particles becomes weaker and the composite also shows a poor mechanical property. As a result, a moderate particle size of diamond is a guarantee to the improved mechanical property. 
Figure 5 shows the effects of diamond content on the bending strength and thermal conductivity of diamond-SiC-Si composites. The result shows that the thermal conductivity of the composites increases with the diamond content. In our experiment, the maximum content of diamond is $80 \mathrm{wt} \%$, and the corresponding thermal conductivity reaches a maximum value of $280 \mathrm{~W} \cdot \mathrm{m}^{-1} \cdot \mathrm{K}^{-1}$. On the other hand, the bending strength decreases with the increase of the diamond content. With the increase of the diamond content, the corresponding carbon from the phenolic resin decreases, thus the content of formed $\mathrm{SiC}$ matrix is reduced, which results in a less bonding between the diamond particles and has a negative effect on the bending strength of diamond-SiC-Si composite.

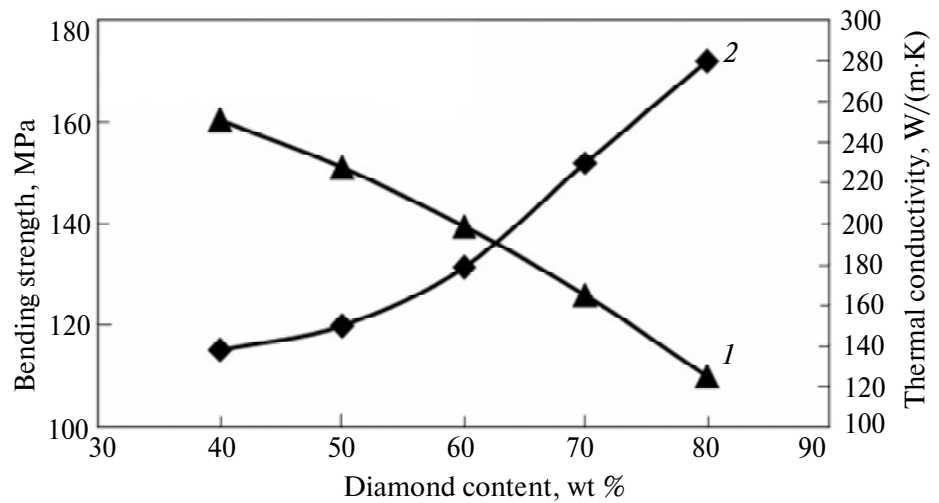

Fig. 5. Effects of diamond content on the bending strength (1) and thermal conductivity (2) of diamond-SiC-Si composites (all the samples have the same mean diamond particle size of $300 \mu \mathrm{m})$.

Figure 6 shows SEM micrographs of a green body and diamond-SiC-Si composite with a diamond particle size of $300 \mu \mathrm{m}$. It can be seen from the SEM micrographs of the green body that the pyrolytic carbon distributes homogeneously around the diamond (see Fig. 6, a). Moreover, the diamond and pyrolytic carbon are loosely distributed in the green body, which provides the infiltration channel for the gaseous silicon infiltration. Diamond was surrounded with pyrolytic carbon derived from phenolic resin, so gaseous $\mathrm{Si}$ will firstly react with pyrolytic carbon to form a compact $\mathrm{SiC}$ coating around diamond [13]. As shown in Fig. 6, $b$, the diamond particles are distributed homogeneously in the composites. Besides, the composite has a dense matrix between the particles, indicating the effective densification of the gaseous Si infiltration. It is also observed that the surfaces of a few diamond particles are eroded slightly despite the protection from the compact $\mathrm{SiC}$ coating, because the loose structure between diamond particles and the pyrolytic carbon provide the interstices for the $\mathrm{Si}$ vapor infiltration.

\section{CONCLUSIONS}

Diamond-SiC-Si composites with high thermal conductivity have been prepared by gaseous silicon vacuum infiltration process. The obtained diamond$\mathrm{SiC}-\mathrm{Si}$ composite is composed of $\beta-\mathrm{SiC}$, diamond, and residual $\mathrm{Si}$. The particle size and content of diamond have strong effects on the properties of diamond-SiC$\mathrm{Si}$ composites. The thermal conductivity of the composites increases with the increase of particle size and content of diamond. On the other hand, a moderate particle size and relatively lower content of diamond is beneficial to the bending strength. When the particle size and content of diamond are $300 \mu \mathrm{m}$ and $80 \mathrm{wt} \%$, 
respectively, the composite has a thermal conductivity of $280 \mathrm{~W} \cdot \mathrm{m}^{-1} \cdot \mathrm{K}^{-1}$ and a bending strength of $107 \mathrm{MPa}$. The diamond-SiC-Si composite has a homogeneous distribution of diamond in the dense matrix. Moreover, the diamond is not severely eroded due to the protection of pyrolytic carbon.

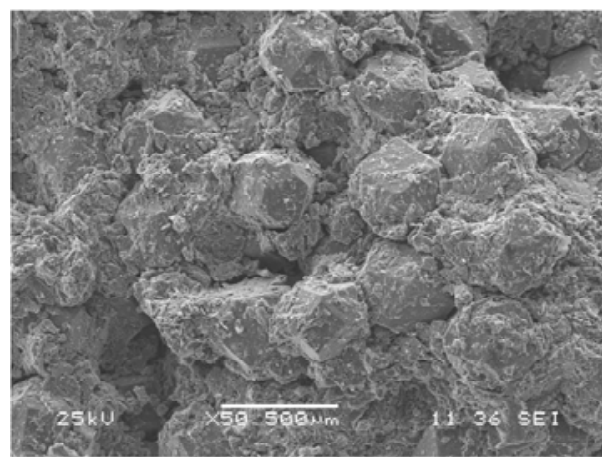

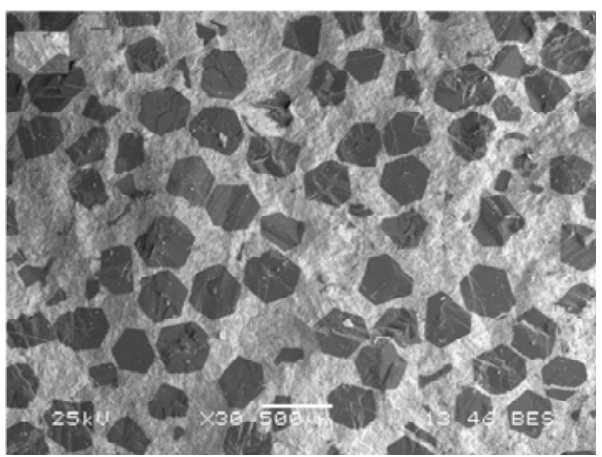

$b$

Fig. 6. Typical cross-sectional SEM micrographs of $(a)$ green body and $(b)$ diamond-SiC-Si composite.

This work was financially supported by the National Natural Science Foundation of China (grant no. 51102282) and Aid Program for Science and Technology Innovative Research Team in Higher Educational Institutions of Hunan Province.

Проведен анализ эволюиии фаз и микроструктуры композитов алмаз$\mathrm{SiC}-\mathrm{Si}$, изготовленных с использованием прочесса вакуумной инфильтрации газообразного кремния. Исследование выполнено с помощью дифракиии рентгеновских лучей и сканирующей электронной микроскопии. Установлено, что композит алмаз-SiC-Si coстоит из $\beta$-SiC, алмаза и остаточного Si. Алмазные частищь распределены однородно в плотной матрице композитов. Также проанализировано влияние размера частиц и содержания алмазов на свойства композитов алмаз-SiC-Si. Показано, что теплопроводность композитов возрастает с увеличением размера частии и содержания алмазов. Теплопроводность композитов приближается к значению $280 \mathrm{Bm}: \mathrm{M}^{-1} \cdot \mathrm{K}^{-1}$ при размере частии и содержсании алмаза 300 мкм и $80 \%$ (по массе), соответственно.

Ключевые слова: композиты алмаз-SiC-Si, микроструктура, эволюиия фаз, вакуумная инфильтрачия, теплопроводность, дифракция рентгеновских лучей, сканирующзая электронная микроскопия.

Проведено аналіз еволюиії фаз і мікроструктури композитів алмаз$\mathrm{SiC}-\mathrm{Si}$, виготовлених з використанням прочесу вакуумної інфільтрачії газоподібного кремнію. Дослідження виконано за допомогою дифракиї рентгенівських променів $і$ скануючої електронної мікроскопії. Встановлено, що композит алмаз-SiC-Si складається $з$ $\beta$-SiC, алмазу $i$ залишкового Si. Алмазні частки розподілені однорідно в щільній матричі композитів. Також проаналізовано вплив розміру частинок $і$ вмісту алмазів на властивості композитів алмаз-SiC-Si. Показано, щзо теплопровідність композитів зростає зі збільшенням розміру частинок і вмісту алмазів. Теплопровідність композитів наближається до значення $280 \mathrm{Bm}: \mathrm{M}^{-1} \cdot \mathrm{K}^{-1}$ при розмірі частинок $i$ вмісту алмазу 300 мкм $і 80 \%$ (за масою) відповідно.

Ключові слова: композити алмаз-SiC-Si, мікроструктура, еволючія фаз, вакуумна інфільтрація, теплопровідність, дифракція рентгенівських променів, скануюча електронна мікроскопія.

1. Ekimov E. A., Suetin N. V., Popovich A. F., Ralchenko V. G. Thermal conductivity of diamond composites sintered under high pressures // Diamond Relat. Mater. - 2008. - 17, N 4. P. 838-843. 
2. Zhang Q. M. Research on ceramic matrix composites (CMC) for aerospace applications // Adv. Mater. Res. - 2011. - 284. - P. 324-329.

3. Herrmann M., Matthey B., Höhn S. et al. Diamond-ceramics composites-New materials for a wide range of challenging applications // J. Eur. Ceram. Soc. - 2012. - 32, N 9. - P. 19151923.

4. Ko Y. S., Tsurumi T., Fukunaga O., Yano T. High pressure sintering of diamond-SiC composite // J. Mater. Sci. - 2001. - 36. - P. 469-475.

5. Voronin G. A., Zerda T. W., Qian J. et al. Diamond-SiC nanocomposites sintered from a mixture of diamond and silicon nanopowders // Diamond Relat. Mater. - 2003. - 12, N 9. P. $1477-1481$.

6. Voronin G. A., Zerda T. W., Gubicza J. et al. Properties of nanostructured diamond-silicon carbide composites sintered by high pressure infiltration technique // J. Mater. Res. - 2004. 19, N 9. - P. 2703-2707.

7. Mlungwane K., Herrmann M., Sigalas I. The low-pressure infiltration of diamond by silicon to form diamond-silicon carbide composites // J. Eur. Ceram. Soc. - 2008. - 28, N 1. - P. 321326.

8. Nauyoks S., Wieligor M., Zerda T. W. et al. Stress and dislocations in diamond-SiC composites sintered at high pressure, high temperature conditions // Composites. Part A. - 2009. - 40, N 5. - P. 566-572.

9. Gordeev S. K., Zhukov S. G., Danchukova L. V., Ekstrom T. C. Low-pressure fabrication of diamond-SiC-Si composites // Inorg. Mater. - 2001. - 37, N 6. - P. 579-583.

10. Mlungwane K. The development of a diamond-silicon carbide composite material// Ind. Diamond Rev. - 2005. - 4. - P. 62-65.

11. Pat. 6709747 US (B1), IPC C04B35/52. Method of manufacturing a diamond composite and a composite produced by same / S. K. Gordeev, S. G. Zhukov, L. V. Danchukova, T. Ekstrom. - Publ. 23.03.04.

12. Wang H. L., Zhou X. G., Yu J. S. et al. Microstructure, mechanical properties and reaction mechanism of $\mathrm{KD}-1 \mathrm{SiC}_{\mathrm{f}} / \mathrm{SiC}$ composites fabricated by chemical vapor infiltration and vapor silicon infiltration // Mater. Sci. Eng. A. - 2011. - 528, N 6. - P. 2441-2445.

13. Qu X. H., Liu R. J., Yang Z. L. et al. Microstructural characterization of diamond/SiC composites fabricated by RVI // Key Eng. Mater. - 2012. - 512. - P. 1105-1110.

14. Wang H. L., Zhou X. G., Yu J. S. et al. Fabrication of SiCf/SiC composites by chemical vapor infiltration and vapor silicon infiltration // Mater. Lett. - 2010. - 64, N 15. - P. 1691-1693.

15. Gubicza J., Ungar T., Wang Y. et al. Microstructure of diamond-SiC nanocomposites determined by X-ray line profile analysis // Diamond Relat. Mater. - 2006. - 15, N 9. - P. 1452 1456 .

Science and Technology on Advanced Ceramic Fibers

Received 24.01.14

and Composites Laboratory, National University

of Defense Technology, Changsha, China 